\title{
Response of Cattleya Hybrids for Fusarium oxysporum f. sp. cattleyae Foster
}

\author{
Cristiano Pedroso-de-Moraes ${ }^{1,2 *}$, Marcelo Claro de Souza $^{2}$, Cínthia Cristina Ronconi ${ }^{3}$ and \\ Marco Aurélio Marteline ${ }^{1}$ \\ ${ }^{I}$ Núcleo de Ciências Ambientais; Centro Universitário Hermínio Ometto; Av. Maximiliano Baruto, 500, 13607-339; \\ Araras - SP - Brasil. ${ }^{2}$ Departamento de Botânica; Universidade Estadual Paulista; C. P.: 199; 13506-900; Rio \\ Claro - SP - Brasil. ${ }^{3}$ Orquidácea; Estrada Municipal de Itapema, 4415; C. P.: 06; 08900-000; Guararema - SP - \\ Brasil
}

\begin{abstract}
The Cattleya genus has a great importance in the flower agro-business market. Fusarium wilts, caused by Fusarium oxysporum $f$. sp. cattleyae, is considered one of the main factors of decline and death of plants of this genus. Using seven hybrids (intra and intergenerics) of Cattleya, tests of resistance and susceptibility to $\mathrm{F}$. oxysporum were performed in conditions of greenhouse for 12 months, using, as evaluation criterion, a scale of the disease severity ranging from one (resistant) to eight (highly susceptible). High susceptibility to the fungus by Cattleya Nobile's Wax Toy, Cattleya Orquidacea's Mister Fast intrageneric hybrids and Potinara Orquidacea's Havana Brown intergeneric hybrid, related to Brassocattleya Orquidacea's Melody intergeneric hybrid, high resistance to the pathogens was observed.
\end{abstract}

Key words: Fusarium wilts, orchid, varietal resistance

\section{INTRODUCTION}

Orchids are very appreciated flowers worldwide (Oliveira and Sajo, 1999), but have high cost of production in the Latin American countries (Trujillo and Hernández, 1999). Commercially, the cultivation of species of Cattleya has great importance for the flower agro-business market mainly due to the large ability of genetic recombination, beauty, shape, size and durability of the flowers (Zanenga-Godoy and Costa, 2003; Moreira and Isaias, 2008). Several regions in São Paulo State have excellent climate conditions for the commercial cultivation of Cattleya and similar hybrids, that means, annual average temperature nearly $28^{\circ} \mathrm{C}$, luminosity intensity around 150 $\mu \mathrm{mol} . \mathrm{m}^{-2} \cdot \mathrm{s}^{-1}$ and $65 \%$ of air relative humidity throughout the year (Pedroso-de-Moraes et al., 2006).

Due to the climatic factor and the good easiness of production flowing off by the proximity to large wholesale centers, the State of São Paulo has most of the orchid national commercial producers (the number estimated to be about 50 orchidgrower companies). The world orchid production is of about 80 billion dollars a year, $40 \%$ of which is directly related to the growing of Cattleya Lindl. (Singh, 1998).

Gioria (2006) reported that incorrect cultivation systems, climate changes (especially temperature

*Author for correspondence: pedroso@uniararas.br 
and rain), decrease of natural enemies by the indiscriminate use of phytosanitary products favor the settlement and colonization of plants by phytopathogenic fungi, represent serious problems for the producers because the lack of information about the desease occurs in certain genus (Coutinho, 1998; Blossfeld, 1999). These aspects represents a limiting factor for the production of orchids by the small and medium size producers in Brazil. The fusarium wilts, caused by the Fusarium oxysporum f. sp. cattleyae fungus is considered as one of the main factors of decline and death of plants of the Cattleya genus (Coutinho, 1998; Gioria, 2002; 2006). Besides the fusarium wilts, several other fungal diseases were detected in national commercial orchid houses, where they were introduced by the presence of spores which were present on the substrates of imported plants without phytosanitary control (Coutinho, 2001).

The radicular system pathogens, mainly those ones which cause vascular diseases, are very difficult to be controlled (Sônego and Valdebenito-Sanhueza, 1992). The infection occurs by the roots or injuries in rhizomes during the vegetative propagation of plants. Such infectim is favored by the temperatures between $25^{\circ} \mathrm{C}$ and $30^{\circ} \mathrm{C}$, that is, the ideal one for the cultivation of Cattleya (Coto, 2007). Unfortunately, methods of chemical control are inefficient for the fusarium wilts of Cattleya (Gioria, 2002; 2006).

The main symptoms of the fusarium wilts in Cattleya start in the roots and develop in ascendant way up to the leaves; these symptoms result in flabby organs that stand out easily of the pseudobulbs (Gioria, 2002; 2006).

In rhizomes, infections generate a discoloration which comes from the action of toxins produced by the pathogen or a dark purple coloration band or circle in the epidermis and hypodermis, which initially exhibit vascular bundles of visible light purple coloration, result of the siege of the conductor vessels, not only by the fungus itself, but also by its spores (Gioria, 2006; Coto, 2007). These symptoms are more visible in the oldest parts of the plants, and even if the new sprouts keep swollen and green, as time goes by, they end up acquiring the symptomathology described (Coto, 2007), and plants severely colonized can die in three to nine weeks (Gioria, 2002; 2006). Due to the temporary suppression of the pathogen and the increase of production costs by the use of fungicides, the use of resistant varieties is the preferred control method since it is the cheapest and easiest to be used and, is exceptionally desirable for the cases of fusarium wilts.

The present work aimed to evaluate the behavior of intra and intergeneric hybrids of Cattleya to the infections of $F$. oxysporum f. sp. cattleyae in the greenhouse, for use in hybridation programs.

\section{MATERIAL AND METHODS}

The experiments were performed in the greenhouse, at the Centro Universitário Hermínio Ometto - UNIARARAS, Araras - SP. Twenty plants of each one of seven varieties (Table 1), with a completely randomized design distributed on four repetition containing five plants for each one. The cultivars evaluated were donated by the Orchid Company, located in Guararema - SP, coming from healthy intra and intergeneric hybrids and in physiological maturity of Cattleya. The samples of unfibered coir of plant-based substrates colonized by $F$. oxysporum were used as inoculum source of $F$. oxysporum f. sp. Cattleyae. The confirmation and identification of the pathogen was performed by PCR analyses (Bakan et al., 2000). For the cultivars replanting (Table 1), plastic pots of $10 \mathrm{~cm}$ of height X $15 \mathrm{~cm}$ of diameter were used, making use of substrate from coconut fiber and inoculated according to the methodology described by Costa et al. (2003).

Table 1 - Intra and intergeneric hybrids (1 intrageneric hybrids; 2 intergeneric hybrids) in physiologic maturity of species of the Cattleya genus used for determining the resistance to Fusarium oxysporum f. sp. cattleyae during the year of 2007.

\begin{tabular}{|c|c|}
\hline Hybrids & Origin \\
\hline Cattleya Nobile`s Wax Toy ${ }^{(1)}$ & Cattleya Lulu X Cattleya guttata \\
\hline Cattleya Orquidacea`s Mister Fast ${ }^{(1)}$ & Cattleya Dinah X Cattleya guttata \\
\hline Brassocattleya Orquidacea`s Melody ${ }^{(2)}$ & Cattleya Cynthia Models X Brassocattleya Roberto Cardoso \\
\hline Brassocattleya Orquidacea`s Rei Sol ${ }^{(2)}$ & Cattleya Culminant X Brassocattleya Roberto Giorchino \\
\hline Brassocattleya Orquidacea`s Rare Bird ${ }^{(2)}$ & Brassocattleya Memoria G. Suzuki X Brassocattleya Haw Moon \\
\hline Brassocattleya Orquidacea`s Samuel Jorge Mello ${ }^{(2)}$ & Brassocattleya Golden Bay X Brassocattleya Waianae Treasure \\
\hline Potinara Orquidacea`s Havana Brown ${ }^{(2)}$ & Potinara Luna Jaune X Brassocattleya Port Royal Sound \\
\hline
\end{tabular}


During twelve months after the replanting, the plants were evaluated montly for the susceptibility and resistance to the pathogen from the observation of typical external symptoms of the disease. The following score system used by Galotti (1991) was adapted: (1 - lack of symptoms in the roots; 2 - lack of discoloration in the pseudobulbs; 3 - lack of withering in the pseudobulbs; 4 - lack of foliar withering; 5 excessive foliar anthocyanin accumulation; 6 lack of foliar discoloration; 7 - accumulation of anthocyanin in sprouts; 8 - atrophy in sprouts). Were the being the cultivars which received grades 1 and 2 considered resistant; from 2 to 3 , moderatedy resistant and above 3 , susceptible to fusarium wilt.

\section{RESULTS AND DISCUSSION}

The intrageneric hybrids Cattleya Nobile's Wax Toy, Cattleya Orquidacea's Mister Fast and the intergeneric hybrid Potinara Orquidacea's Havana Brown were the most susceptible to the pathogen. All individuals died eight months after the beginning of the experiment with all the characteristic symptoms of the $F$. oxysporum $\mathrm{f}$. sp. cattleyae infection (Figure 1). The Brassocattleya Orquidacea`s Rare Bird hybrid showed moderate resistance to the phytopathogen in $65 \%$ of the cases and $35 \%$ of the plants from the five lots showed resistance to the fungus (Tables 2 and 3; Figure 2); Brassocattleya Orquidacea`s Rei Sol and Brassocattleya Orquidacea's Samuel Jorge Mello (Tables 2 and 3; Figure 2) showed susceptibility to fusarium wilts; $85 \%$ was of them were affected, and, consequently, it is not recommended for the development of hybrids in the areas infected by $F$. oxysporum.

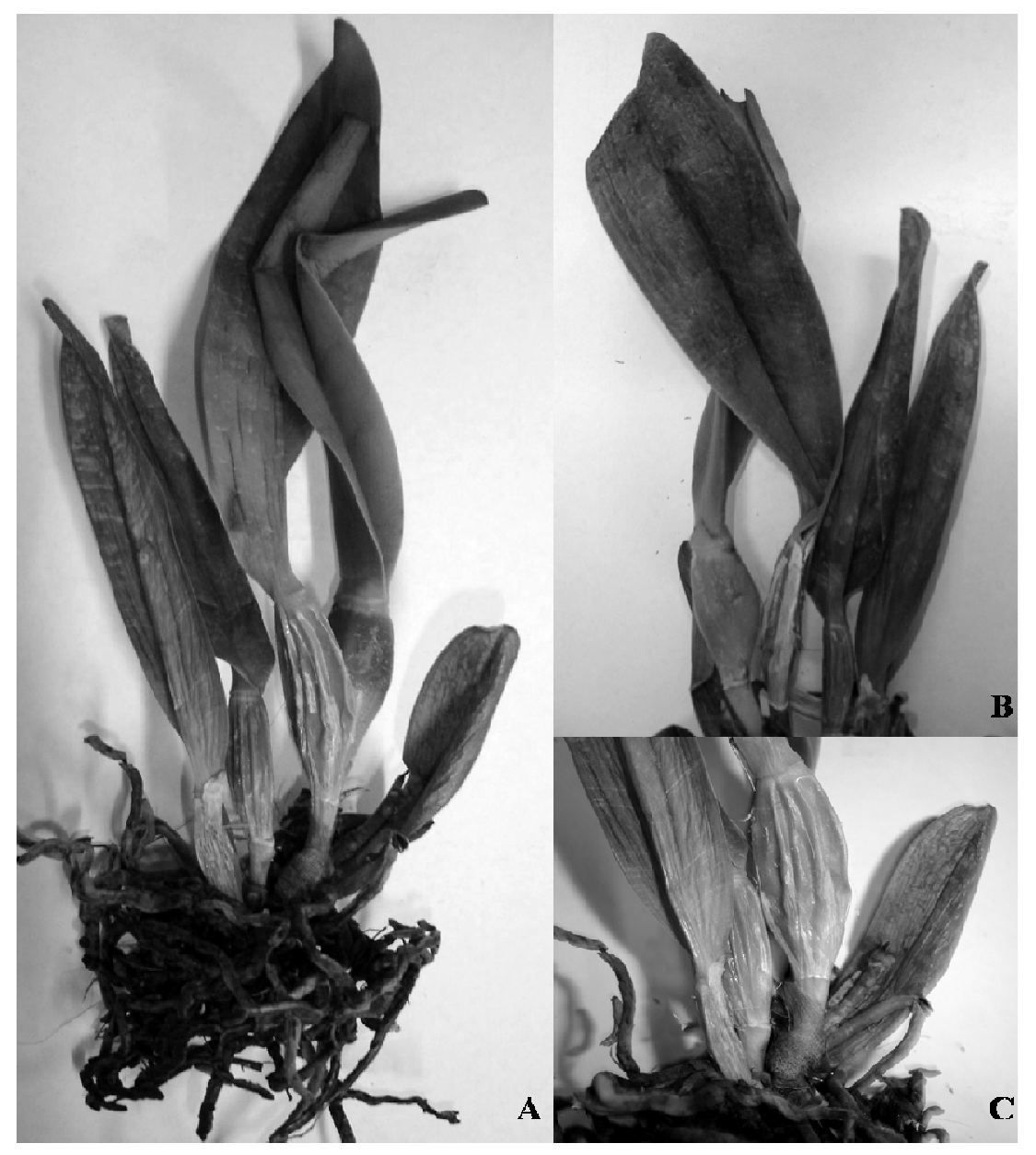

Figure 1 - Potinara Orquidacea`s Havana Brown. In A, view of plant infected by Fusarium oxysporum f. sp. cattleyae. B, the aspect of the leaves after two months of infection. C, detail of the pseudobulbs and flabby roots. 
Table 2 - Reaction of intra and intergeneric hybrids in physiologic maturity of Cattleya species expressed in degree of infection for the determination of resistance to Fusarium oxysporum f. sp. cattleyae during the year of 2007. Degrees of infection: 1 resistant; 2 moderated resistant; 3 little resistant and 4 susceptible to fusarium wilt. Degrees of Resistance: $\mathrm{R}$ - resistant; $\mathrm{MR}$ - moderated resistant and $\mathrm{S}$ - susceptible.

\begin{tabular}{lcc}
\hline Crossings and Hybrids & Degree of Infection & Degree of Resistance \\
\hline Cattleya Nobile`s Wax Toy & 4,0 & $\mathrm{~S}$ \\
Cattleya Orquidacea`s Mister Fast & 4,0 & $\mathrm{~S}$ \\
Brassocattleya Orquidacea`s Melody & 1,0 & $\mathrm{R}$ \\
Brassocattleya Orquidacea`s Rei Sol & 3,5 & $\mathrm{~S}$ \\
Brassocattleya Orquidacea`s Rare Bird & 2,5 & $\mathrm{MR}$ \\
Brassocattleya Orquidacea`s Samuel J. Mello & 3,5 & $\mathrm{~S}$ \\
Potinara Orquidacea`s Havana Brown & 4,0 & $\mathrm{~S}$ \\
\hline
\end{tabular}

Table 3 - Reaction of the intra and intergeneric hybrids in physiologic maturity of Cattleya species in percentage (\%) for each degree of resistance to the infection of Fusarium oxysporum f. sp. cattleyae during the year of 2007. Degrees of infection: $\mathrm{R}$ - resistant; $\mathrm{MR}$ - moderated resistant and $\mathrm{S}$ - susceptible.

\begin{tabular}{llccc}
\hline Crossings and Hybrids & \multicolumn{3}{c}{ \% Degree of Infection } \\
\cline { 2 - 6 } Cattleya Nobile`s Wax Toy & MR & S & Total \\
Cattleya Orquidacea`s Mister Fast & 0 & 0 & 100 & 100 \\
Brassocattleya Orquidacea`s Melody & 0 & 0 & 100 & 100 \\
Brassocattleya Orquidacea`s Rare Bird & 100 & 0 & 0 & 100 \\
Brassocattleya Orquidacea`s Samuel Jorge Mello & 38 & 62 & 0 & 100 \\
Brassocattleya Orquidacea`s Rei Sol & 0 & 15 & 85 & 100 \\
Potinara Orquidacea`s Havana Brown & 0 & 17 & 83 & 100 \\
\hline
\end{tabular}

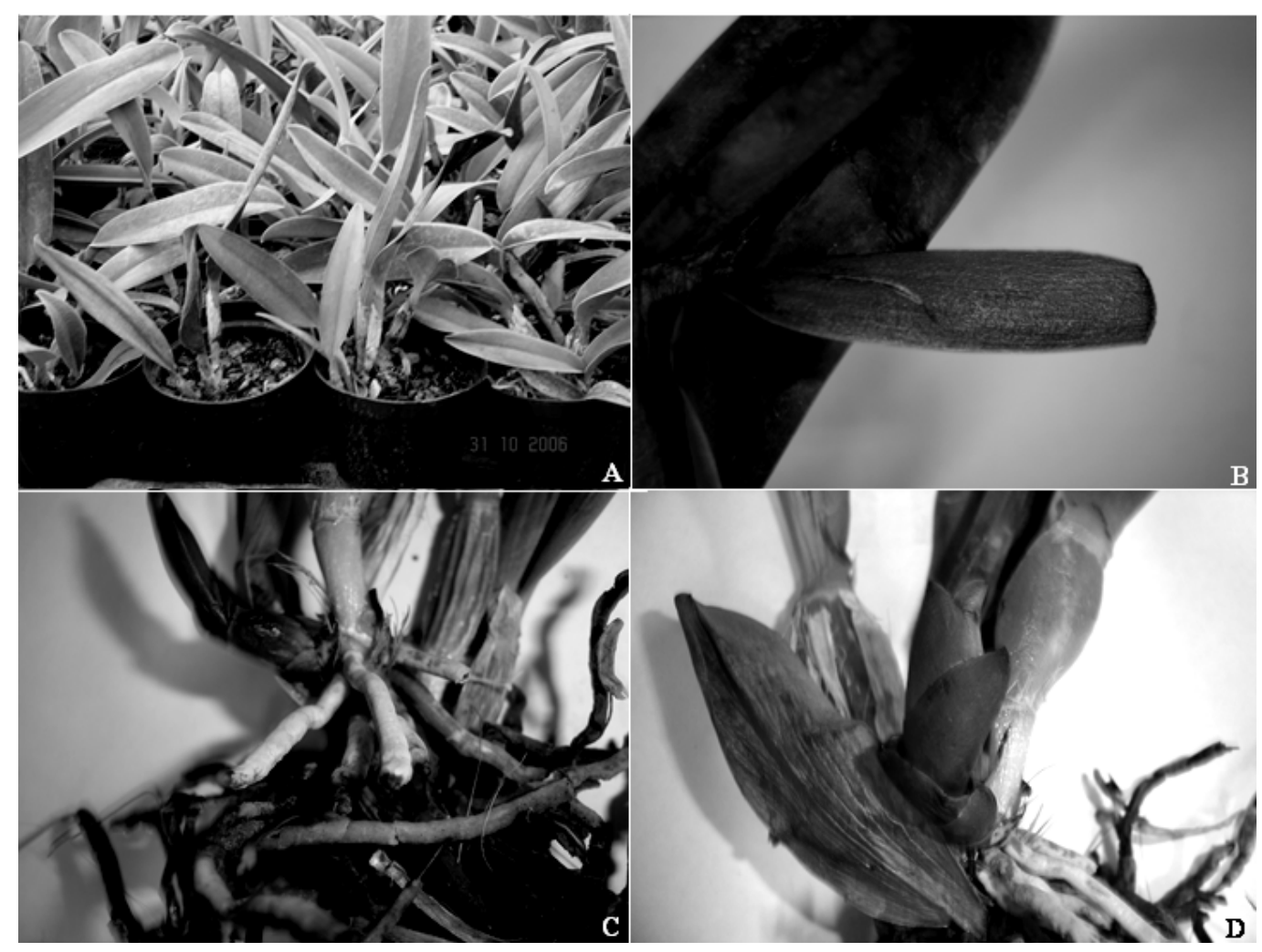

Figure 2 - A, treatment containing Brassolaeliocattleya Orquidacea's Rare Bird. B, accumulation of the anthocyanin due to the infection by Fusarium oxysporum f. sp. cattleyae in Brassocattleya Orquidacea`s Rei Sol leaves. In C and D, flabby roots and atrophied sprout, respectively, in plants of Brassocattleya Orquidacea`s Samuel Jorge Mello. 
Infections by the $F$. oxysporum f. sp. cattleyae were not seen in Brassocattleya Orquidacea's Melody hybrid, possibly due to the factors, such as evolutionary and environmental adaptations, and mainly due to gene recombinations. Hence this cultivar was resistant to phytopathogen, and should be used for crossings and hybridizations aiming to achieve the resistance in future lineages (Johnson, 1984).

Control measures mentioned in the literature for the diseases in tropical ornamental plants, such as fertilization handling, planting and irrigation system (Coelho and Warumby, 2002) many times are not effective. The chemical control has been used in an empiric way, without any validity in previous scientific researches. Thus, the use of resistant cultivars would represent an attractive control alternative for the main tropical flowers disease, besides being more economically feasible and avoiding the environmental contamination by the use of fungicides (Serra and Coelho, 2007).

\section{REFERENCES}

Bakan, B., Ciraud-Delville, C., Pinson, L.; RichardMollard, D., Fournier, E., Brygoo, Y. (2000), Identification by PCR of Fusarium culmorum strains producing large and small amounts of deoxynivalenol. Appl. Environ. Microbiol., 68, 54725479.

Blossfeld, A. (1999), Orquidologia, Orquidofilia e Orquicultura. Editora Funep. São Paulo.

Coelho, R.S.B., Warumby, J.F. (2002), Doenças de plantas ornamentais tropicais detectadas na Zona da Mata de Pernambuco. Floricult. Pernamb., 1, 67-69.

Costa, M.L.N., Machado, J.C., Guimarães, R.M., Pozza, E.A., Oride, D. (2003) Inoculação de Fusarium oxysporum f. sp. phaseoli em sementes de feijoeiro através de restrição hídrica. Ciênc. agrotec., 27, 1023-1030.

Coto, G.R. (2007), Epidemiología de las enfermedades fungosas en orquídeas. Tricorquideas. San José.

Coutinho, L.N., Tofoli, J.G., Takada, H.M., Figueiredo, M.B. (1998), Aspectos fitossanitários das orquídeas. Doenças fúngicas. In: Bergmann, E.C., Alexandre, M.A.V. (Coords.). Aspectos fitossanitários das orquídeas. São Paulo: Instituto Biológico.
Coutinho, L.N. (2001), Problemas de introdução de doenças por meio de aquisição de plantas ornamentais exóticas. Biológico. São Paulo.

Galotti, G.J.M. (1991), Avaliação da resistência de Vittis spp. a Fusarium oxysporum f. sp. herbemontis. Fitopatol. bras., 16, 74-77.

Gioria, R. (2002), D and P que atacam as orquídeas. Editora Brasil Orquídeas Ltda. Taubaté, São Paulo.

Gioria, R. (2006), Pragas e doenças na orquidofilia. Clube da Orquídea. São Paulo.

Johnson, R. (1984), A critical analysis of durable resistence. Annu. Rev. Phytopathol., 22, 309-330.

Moreira, A.S.F.P., Isaias, R.M.S. (2008), Comparative anatomy of the absorption roots of terrestrial and epiphytic orchids. Braz. arch. biol. technol., 51, 8393.

Oliveira, V.C., Sajo, M.G. (1999), Root anatomy of nine Orchidaceae species. Braz. arch. biol. technol., 42, 405-413.

Pedroso-de-Moraes, C., Canabrava, R. I., Pedro, N. P., Diogo, J.A., Marteline, M.A., Sommer, J.R., Favetta, M.M.S. (2006), Tendências na comercialização de orquídeas no município de Santa Cruz das Palmeiras. Paper presented at I Congresso Científico e I Congresso de Iniciação Científica - Uniararas, 23-27 Aug, Araras, São Paulo.

Serra, I.M.R.S., Coelho, R.S.B. (2007), Mancha pestalotiopsis em Helicônia: caracterização da doença e potenciais fontes de resistência. Fitopatol. bras., 32, 44-49.

Singh, F. (1998), Post haversting handling and packaging of orchid flowers (Edited). Indian Inst. Of Hort. Res. (Upper Palace Orchads, Bangalore).

Sônego, O.R., Valdebenito-Sanhueza, R.M. (1992), Perpectivas do biocontrole de Fusarium oxysporum $\mathrm{f}$. sp. herbemontis. Hortisul, 4, 48-51.

Trujillo, G., Hernández, Y. (1999). Bacterial spot in orchid. Fitopatal. Venezoel., 12, 4-8.

Zanenga-Godoy, R., Costa, C.G. (2003), Anatomia foliar de quatro espécies do gênero Cattleya Lindl. (Orchidaceae) do Planalto Central Brasileiro. Acta Bot. Bras., 17, 101-118.
Received: August 02, 2009; Revised: February 02, 2010; Accepted: September 14, 2010. 